\title{
Treatment Regimen \#3
}

National Cancer Institute

\section{Source}

National Cancer Institute. Treatment Regimen \#3. NCI Thesaurus. Code C159876.

The third treatment regimen. 